\title{
Extracellular Accumulation of Organic Acids by Isopropanol-utilizing Microorganisms
}

\author{
Akio Sato, Terunobu Misono and Yuichi MiURA* \\ Fermentation Research Institute, Inage, Chiba \\ *Tokuyama Soda Co., Ltd., Tokuyama, Yamaguchi-ken
}

Received December 4, 1975

\begin{abstract}
Isopropanol-utilizing microorganisms were newly isolated from soils and several of them accumulated two acids in the culture broth, $\alpha$-ketoglutaric acid being a major one and succinic acid a minor one. Two strains ( $\mathrm{N}-79$ and S-1), classified as the genus Mycobacterium, were examined for the cultural conditions with respect to the accumulation of the acids. The accumulation of $\alpha$-ketoglutaric acid depended greatly on the $\mathrm{pH}$ value in the broth, which is required to be kept at around 4 for the maximum accumulation. By means of the pHcontrolled culture (at 3.5) with a jar fermentor, strain $\mathrm{N}-79$ accumulated $\alpha$-ketoglutaric acid at a rate of $0.015 \mathrm{~g} / \mathrm{liter} / \mathrm{hr}$. The data obtained in this work indicate that the metabolism of isopropanol by strain $\mathrm{N}-79$ probably proceeds via the acetone pathway without the interconversion between isopropanol and $n$-propanol.
\end{abstract}

There have been many reports on the utilization of lower alcohols as raw materials for fermentation, but relatively few reports on the utilization of isopropanol. Biomass production, ${ }^{1}$ acetone production's' and L-glutamate production $^{3 /}$ from isopropanol have been reported recently. Among lower alcohols, isopropanol is considered to be a favorable raw material next to methanol, according to the economic assessment of lower alcohols for biomass production made by Takahashi."

A work, therefore, was undertaken on the fermentative production of useful extracellular metabolites from this carbon source. A number of microorganisms which could grow on isopropanol as the sole carbon source were isolated from soils, and several strains were found to accumulate $a$-ketoglutaric and succinic acids in the culture broth. This paper will describe the taxonomical and cultural characteristics of the strains producing the acids from isopropanol.

\section{MATERIALS AND METHODS}

1. Isolation of isopropanol-utilizing microorganisms. Soil samples were incubated in the medium composed of isopropanol $10 \mathrm{ml},\left(\mathrm{NH}_{4}\right)_{2} \mathrm{SO}_{4} 3 \mathrm{~g}, \mathrm{KH}_{2} \mathrm{PO}_{4} 1.5 \mathrm{~g}$, $\mathrm{Na}_{2} \mathrm{HPO}_{4} 1.5 \mathrm{~g}, \quad \mathrm{MgSO}_{4} \cdot 7 \mathrm{H}_{2} \mathrm{O} 0.5 \mathrm{~g}, \quad \mathrm{FeSO}_{4} \cdot 7 \mathrm{H}_{2} \mathrm{O}$
$0.02 \mathrm{~g}, \quad \mathrm{CaCl}_{2} \cdot 2 \mathrm{H}_{2} \mathrm{O} \quad 0.02 \mathrm{~g}, \quad \mathrm{MnSO}_{4} \cdot n \mathrm{H}_{2} \mathrm{O} \quad 0.002 \mathrm{~g}$, yeast extract $0.2 \mathrm{~g}$ and distilled water 1 liter $(\mathrm{pH} 7.0$ ). Isopropanol was added aseptically to the medium sterilized at $120^{\circ} \mathrm{C}$ for $15 \mathrm{~min}$. This medium was basically used throughout the work unless otherwise indicated. After the enrichment culture was repeated twice, microorganisms were isolated and purified by the usual methods. Isolated organisms were stocked on agar slants of the same medium.

2. Cultivation. Cells grown on an isopropanol agar slant for 2 to 3 days were inoculated into a $500 \mathrm{ml}$ shaking flask containing $50 \mathrm{ml}$ of the medium and incubated at $30^{\circ} \mathrm{C}$ with reciprocal shaking at $120 \mathrm{rpm}$.

3. Isolation of organic acids. a-Ketoglutaric acid was isolated as its 2,4-dinitrophenylhydrazone derivative in the following way. The supernatant of culture broth was treated with a solution of 2,4-dinitrophenylhydrazine hydrochloride and the resultant hydrazone was extracted with ethyl acetate. The ethyl acetate extract was shaken with a solution of $10 \%$ of sodium carbonate, by which the hydrazone was transferred to the water phase and the excess of hydrazine reagent remained in the organic phase. The water phase, after acidification, was again extracted with ethyl acetate and the extract was evaporated to yield crystals of the hydrazone. Purification was made by recrystallization from a mixture of methanol and water.

Succinic acid was isolated as free acid in the following manner. The supernatant of culture broth was evaporated to a small volume under reduced pressure, acidified below pH 2 and extracted with a large volume of ether. After the ether was removed by evaporation, 
the residue was allowed to stand until crystallization. Crude crystals were purified by repeated recrystallizations from a mixture of ethyl acetate and acetone.

4. Isolation of acetone. Acetone was distilled with heat from the broth and trapped in a solution of 2,4dinitrophenylhydrazine hydrochloride to give precipitates of its hydrazone derivative, which was purified by recrystallization from a mixture of ethanol and water.

5. Determination of organic acids. $\alpha$-Ketoglutaric and succinic acids, after esterification, were determined by gas liquid chromatography according to the procedure shown in Fig. 1. $\alpha$-Ketoglutaric acid, prior to

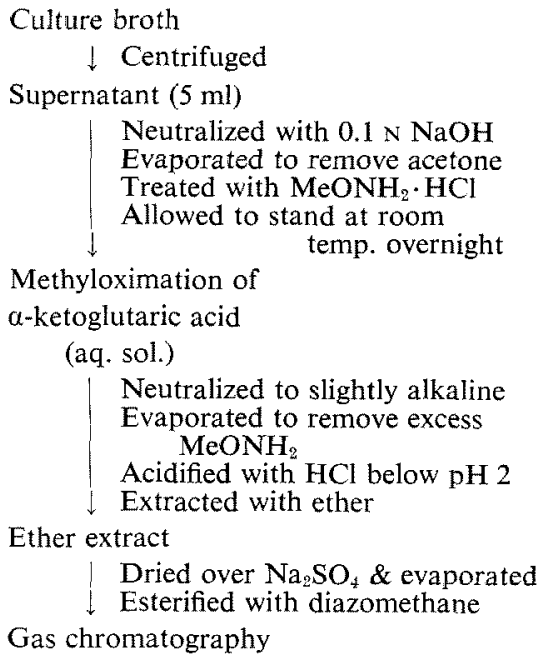

FIG. 1. Determination of $\alpha$-Ketoglutaric and Succinic Acids.

esterification with diazomethane, was converted into a stable form by methyloximation with methoxyamine hydrochloride following Ishitoya's method. ${ }^{5}$ ) Operating conditions of gas liquid chromatography with a Shimadzu model GC-5A were as follows: column, $15 \%$ DEGS on Chromosorb WAW $(60 \sim 80$ mesh) in a $3 \mathrm{~m} \times 4 \mathrm{~mm}$ i.d. stainless steel tube; carrier gas $\left(\mathrm{N}_{2}\right)$, $60 \mathrm{ml} / \mathrm{min}$; column temp., $160^{\circ} \mathrm{C}$. Dimethylglutarate was used as an internal standard for quantitative analysis.

6. Determination of acetone and isopropanol. Acetone and isopropanol in the culture broth were also determined by gas liquid chromatography. After the broth was centrifuged, an aliquot of the supernatant was directly injected, using $n$-butanol as an internal standard, into the column of $15 \%$ PEG-1000 on Shimalite $F(20 \sim 80 \mathrm{mesh})$ in $3 \mathrm{~m} \times 4 \mathrm{~mm}$ i.d. stainless steel tube; the temperatures of the column and the injector being $80^{\circ}$ and $150^{\circ} \mathrm{C}$, respectively.
7. Infrared spectra. Infrared spectra were recorded as $\mathrm{KBr}$ disc with a JASCO model IR-G spectrophotometer.

\section{RESULTS AND DISCUSSION}

\section{Taxonomical characteristics of strain $N-79$ and $S-1$}

Several isopropanol-assimilating isolates were found to produce $\alpha$-ketoglutarate and succinate. Among those, strain $\mathrm{N}-79$ and S-1 were chosen for further study because of their higher productivities of organic acids than those of the others. Their taxonomical characteristics are summarized in Table I.

Table I. Taxonomical Characteristics of Strain N-79 and S-1

1. Strain $\mathrm{N}-79$

Morphological characteristics Gram-positive, acid-fast, non-motile, nonsporing rods $0.4 \sim 0.5$ by $2 \sim 5 \mu$. Branching and pleomorphism not observed.

Cultural characteristics

Nutrient agar colonies: circular $(0.5 \sim 4 \mathrm{~mm}$ in dia.), capitate, undulate, yellowish gray, opaque.

Nutrient agar slant: growth abundant, spreading, rugose, glistening, yellowish gray.

Nutrient broth: pellicle, slightly turbidic, sediment.

Gelatin stab: good growth at surface, no liquefaction.

Milk: not changed.

Litmus milk and BCP milk: alkaline.

Temperature for growth: $10 \sim 40^{\circ} \mathrm{C}$, good growth at $25 \sim 35^{\circ} \mathrm{C}$

pH range for growth: $5 \sim 8$.

Salt tolerancy: growth in $1 \% \mathrm{NaCl}$ broth, not in $3 \% \mathrm{NaCl}$ broth.

Physiological characteristics

Indole production: negative.

Nitrate reduction: positive.

Ammonia production from peptone: positive.

Hydrogen sulfide production: positive.

Hydrolysis of starch: negative.

Voges-Proskauer test: negative.

Methyl red test: negative.

Urease: positive.

Catalase: positive.

Cytochrome oxidase: negative.

Acid without gas from fructose, slowly from glucose and glycerol. 
Neither acid nor gas from arabinose, xylose, galactose, maltose, sucrose, lactose and mannitol.

Cellulose not attacked.

Acetic, propionic, succinic and citric acids assimilated.

\section{Strain $\mathrm{S}-1$}

The organism has a close resemblance to strain $\mathrm{N}-79$ except for the following points: a) characteristics of nutrient agar colonies; circular $(0.5 \sim$ $4 \mathrm{~mm}$ in dia.), umbonate, undulate, yellowish gray opaque. b) neither acid nor gas formation from glycerol.

From these results, the two strains were considered as belonging to the genus Mycobacteri$u m$, but neither of them was identical with any species of the genus described in Bergey's Manual of Determinative Bacteriology (7th and 8th edition). Although they closely resemble each other in many respects, there exist some minor differences such as in acid formation from glycerol and in utilization of various carbon sources as mentioned below.

2. Utilization of various carbon sources by strain $N-79$ and $S-1$

The results are summarized in Table II. Methanol could not sustain any extent of growth of strain $\mathrm{N}-79$ and $\mathrm{S}-1$, and glycols were not good substrates either. Although $n$ propanol was utilized as readily as isopropanol by both of the strains, organic acids were not produced from this carbon source. Strain $\mathrm{N}-79$ showed abundant growth on ethanol and produced $\alpha$-ketoglutaric and succinic acids, whereas strain $\mathrm{S}-1$ could not utilize this carbon source.

\section{Identification of organic acids and acetone}

Strain N-79 was cultivated in the medium containing $2 \%(\mathrm{v} / \mathrm{v})$ of isopropanol for 7 days. The culture broth, when subjected to thin layer chromatography, gave two bromocresol green-positive spots on a silica gel plate developed with $n$-butanol-acetic acid-water $(4: 1: 1)$. Two acids were isolated and purified as mentioned above. By comparison with the authentic specimens, a major acid was
Table II. Utilization of Various Carbon Sources by Strain N-79 aNd S-1

Cultivation was carried out at $30^{\circ} \mathrm{C}$ for 7 days.

\begin{tabular}{|c|c|c|c|c|}
\hline \multicolumn{2}{|c|}{$\begin{array}{c}\text { Carbon source } \\
\text { (vol. } \%)\end{array}$} & Growth & $\begin{array}{l}\alpha-\text { Ketoglu- } \\
\text { taric acid } \\
(\mathrm{mg} / \mathrm{liter})\end{array}$ & $\begin{array}{l}\text { Succinic } \\
\text { acid } \\
\text { (mg/liter) }\end{array}$ \\
\hline \multicolumn{5}{|l|}{ Strain N-79 } \\
\hline Methanol & 1.0 & - & - & - \\
\hline Ethanol & 2.0 & +++ & 90 & 35 \\
\hline n-Propanol & 2.0 & $+t+$ & - & - \\
\hline Isopropanol & 2.0 & $++t$ & 540 & 190 \\
\hline$n$-Butanol & 1.0 & \pm & - & - \\
\hline Ethyleneglycol & 1.0 & \pm & - & - \\
\hline Propyleneglycol & 1.0 & \pm & - & - \\
\hline Glycerol & 1.0 & \pm & - & - \\
\hline$n$-Paraffins & 2.0 & ++ & - & - \\
\hline Glucose & 1.0 & \pm & - & $一$ \\
\hline Fructose & 1.0 & $+t+$ & 一 & - \\
\hline \multicolumn{5}{|l|}{ Strain S-1 } \\
\hline Methanol & 1.0 & - & - & - \\
\hline Ethanol & 2.0 & - & - & - \\
\hline$n$-Propanol & 2.0 & +++ & - & - \\
\hline Isopropanol & 2.0 & $++t$ & 186 & 40 \\
\hline n-Butanol & 1.0 & - & - & - \\
\hline Ethyleneglycol & 1.0 & + & - & - \\
\hline Propyleneglycol & 1.0 & + & - & - \\
\hline Glycerol & 1.0 & + & 一 & - \\
\hline$n$-Paraffins & 2.0 & ++ & - & - \\
\hline
\end{tabular}

identified as $\alpha$-ketoglutaric acid and a minor one as succinic acid.

Acetone was collected by distillation from the 4 day-culture broth and purified in a form 2, 4-dinitrophenylhydrazone. The results are shown in Table III. The infrared spectra of succinic acid and of 2, 4-dinitrophenylhydrazones of $\alpha$-ketoglutaric acid and acetone were in good accordance with those of their respective authentic specimens.

4. Cultural conditions for accumulation of organic acids

a) Effect of isopropanol concentration. As shown in Table IV, cell mass of strain N-79 increased with an increase in the concentration, up to $3 \%(\mathrm{v} / \mathrm{v})$, of isopropanol but higher concentrations inhibited growth of the organism. For production of the organic acids, $2 \%$ of the isopropanol concentration was shown to be more suitable than $3 \%$. Strain $\mathrm{S}-1$ gave results similar to those obtained with strain 
Table III. Identification of Organic Acids and ACEtone

\begin{tabular}{|c|c|c|c|c|}
\hline & \multicolumn{2}{|c|}{ Melting point } & \multicolumn{2}{|c|}{ Elemental analysis } \\
\hline & Sample & Authentic & Found & Calcd, for \\
\hline Succinic acid & $182 \sim 183^{\circ} \mathrm{C}$ & $182 \sim 183^{\circ} \mathrm{C}$ & $\begin{array}{l}\mathrm{C}, \quad 40.97 \% \\
\mathrm{H}, \quad 5.10\end{array}$ & $\begin{array}{c}\mathrm{C}_{4} \mathrm{H}_{8} \mathrm{O}_{4} \\
\mathrm{C}, 40.68 \% \\
\mathrm{H}, 5.12 \\
\mathrm{C}_{11} \mathrm{H}_{4}\end{array}$ \\
\hline $\begin{array}{l}\text { 2,4-DNP of } \alpha \text {-keto- } \\
\text { glutaric acid }\end{array}$ & $\begin{array}{c}219^{\circ} \mathrm{C} \\
\text { (decomp.) }\end{array}$ & $\begin{array}{c}219^{\circ} \mathrm{C} \\
\text { (decomp.) }\end{array}$ & $\begin{array}{r}\mathrm{C}, 40.74 \\
\mathrm{H}, 3.06 \\
\mathrm{~N}, 17.02\end{array}$ & $\begin{array}{l}\mathrm{C}, 40.50 \\
\mathrm{H}, 3.09 \\
\mathrm{~N}, 17.17\end{array}$ \\
\hline 2,4-DNP of acetone & $124^{\circ} \mathrm{C}$ & $124^{\circ} \mathrm{C}$ & $\begin{array}{l}\mathrm{C}, 45.48 \\
\mathrm{H}, \quad 4.24 \\
\mathrm{~N}, 23.59\end{array}$ & $\begin{array}{r}\mathrm{C}_{9} \mathrm{H}_{10} \mathrm{~N}_{4} \mathrm{O}_{4} \\
\mathrm{C}, 45.38 \\
\mathrm{H}, \quad 4.23 \\
\mathrm{~N}, 23.52\end{array}$ \\
\hline
\end{tabular}

TABLe IV. Effect of Isopropanol Concentration on Accumulation of Organic Acids

Strain $\mathrm{N}-79$ was cultivated at $30^{\circ} \mathrm{C}$ for 7 days.

\begin{tabular}{cccc}
\hline $\begin{array}{c}\text { Conc. of } \\
\text { isopropanol } \\
\text { (vol. \%) }\end{array}$ & Cells & $\begin{array}{c}\alpha \text {-Ketoglu- } \\
\text { taric acid } \\
\text { (mg/liter) }\end{array}$ & $\begin{array}{c}\text { Succinic } \\
\text { acid } \\
\text { (mg/liter) }\end{array}$ \\
\hline 1.0 & 0.7 & 300 & 60 \\
2.0 & 0.8 & 540 & 190 \\
3.0 & 1.5 & 240 & 145 \\
4.0 & - & - & - \\
5.0 & - & - & - \\
\hline
\end{tabular}

$\mathrm{N}-79$ in respect to the concentration of isopropanol.

b) Effect of nitrogen sources. Both strain $\mathrm{N}-79$ and $\mathrm{S}-1$ utilized nitrate and urea as well as ammonium salts as a nitrogen source, but the organic acids were accumulated only when ammonium salts were used (see Table V). The relationship between the concentration of

Table V. Effect of Nitrogen Sources on ACCUMUlation of ORganic Acids

Strain N-79 was cultivated at $30^{\circ} \mathrm{C}$ for 7 days. Similar results were obtained with strain S-1.

\begin{tabular}{lcccc}
\hline N-Source & $\begin{array}{c}\text { Final } \\
\text { pH }\end{array}$ & $\begin{array}{c}\text { Cells } \\
\text { (g/liter) }\end{array}$ & $\begin{array}{c}\text { a-Ketoglu- } \\
\text { taric acid } \\
\text { (mg/liter) }\end{array}$ & $\begin{array}{c}\text { Succinic } \\
\text { acid } \\
(\mathrm{mg} / \text { liter })\end{array}$ \\
\hline$\left(\mathrm{NH}_{4}\right)_{2} \mathrm{SO}_{4}$ & 2.4 & 0.8 & 540 & 190 \\
$\mathrm{NH}_{4} \mathrm{Cl}$ & 2.4 & 1.1 & 490 & 180 \\
$\mathrm{NH}_{4} \mathrm{NO}_{3}$ & 2.8 & 1.2 & 240 & 100 \\
$\left(\mathrm{NH}_{4}\right)_{2} \mathrm{HPO}_{3}$ & 5.6 & 1.7 & - & - \\
$\mathrm{KNO}_{3}$ & 7.4 & 1.3 & - & - \\
Urea & 8.4 & 1.3 & - & - \\
\hline
\end{tabular}

ammonium salt in the medium and the accumulation of the organic acids is shown in Fig. 2. The accumulation of succinic acid was scarcely affected in a wide range of the concentrations of ammonium sulfate, while the accumulation of $\boldsymbol{\alpha}$-ketoglutaric acid markedly increased at a low concentration such as $0.5 \mathrm{~g} /$ liter. At this concentration, the yields of $\alpha$ ketoglutaric acid by strain N-79 and S-1 were $980 \mathrm{mg} /$ liter and $890 \mathrm{mg} /$ liter, respectively.

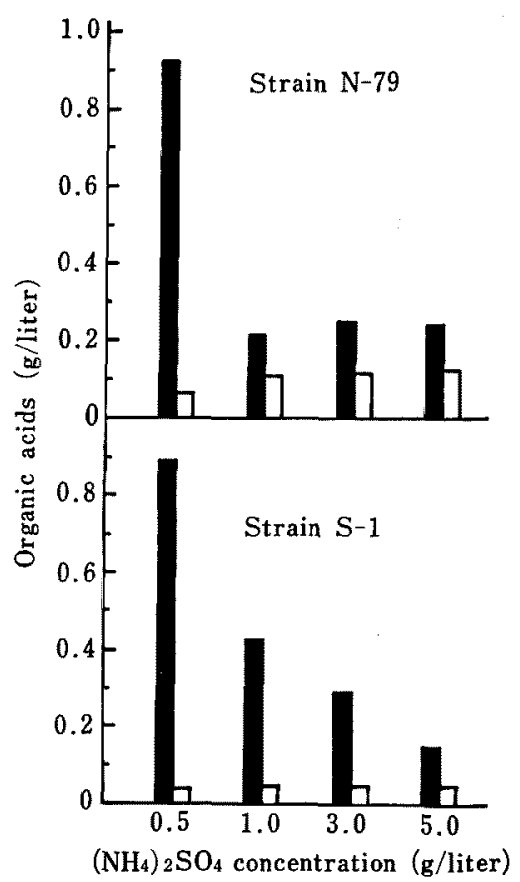

FIG. 2. Effect of $\left(\mathrm{NH}_{4}\right)_{2} \mathrm{SO}_{4}$ Concentration on Accumulation of Organic Acids.

घ, $\alpha$-ketoglutaric acid; $\square$, succinic acid. 
c) Effect of organic nutrients. The effect of various organic nutrients on the accumulation of the major acid ( $\alpha$-ketoglutaric) by strain $\mathrm{N}-79$ is shown in Table VI. The organism

Table VI. Effect of Organic Nutrients on accumulation of $\alpha$-Ketoglutaric Acid Strain N-79 was cultivated at $30^{\circ} \mathrm{C}$ for 7 days.

\begin{tabular}{lcccc}
\hline \multicolumn{1}{c}{\begin{tabular}{c} 
Organic nutrient \\
\multicolumn{1}{c}{ (wt. \%) }
\end{tabular}} & $\begin{array}{c}\text { Final } \\
\text { Yeast extract }\end{array}$ & $\begin{array}{c}\text { Cells } \\
\text { (g/liter) }\end{array}$ & $\begin{array}{c}\alpha \text {-Ketoglu- } \\
\text { taric acid } \\
\text { (mg/liter) }\end{array}$ \\
\hline Peptone & 0.02 & 2.4 & 1.57 & 650 \\
& 0.02 & 2.4 & 2.12 & 400 \\
Malt extract & 0.05 & 3.0 & 1.14 & 160 \\
& 0.02 & 2.6 & 1.06 & 140 \\
Corn steep liquor & 0.05 & 2.4 & 1.06 & 550 \\
& 0.05 & 2.4 & 0.86 & 730 \\
Casamino acids & 0.02 & 2.4 & 1.41 & 640 \\
& 0.05 & 2.4 & 1.76 & 460 \\
Casamino acids & 0.02 & 5.6 & 0.63 & - \\
(vitamin free) & 0.05 & 5.6 & 0.76 & - \\
No nutrient & - & 7.0 & - & - \\
\hline
\end{tabular}

could not grow in the synthetic medium containing no organic nutrient. In the presence of various organic nutrients other than vitamin free casamino acids, $\alpha$-ketoglutaric acid was accumulated without great differences in the yields. When vitamin free casamino acids were used, however, neither $\alpha$-ketoglutaric acid nor other acids including succinic acid were accumulated in any detectable amount. We have no satisfactory explanation for this. The results obtained with stain $\mathrm{S}-1$ showed the same tedencies as those of strain $\mathrm{N}-79$.

d) Effect of initial $p H$ and addition of $\mathrm{CaCO}_{3}$. When the initial $\mathrm{pH}$ of 8.0 was used for strain $\mathrm{N}-79$, no organic acids were accumulated in the broth and the final $\mathrm{pH}$ was maintained at a rather high level $(5.0)$ in comparison with those for the initial $\mathrm{pH} 7.0$ and 6.0 (see Table VII). The addition of precipitated calcium carbonate to the medium, which is usually favorable for the fermentative accumulation of organic acids, had no effect in this case. Strain $S-1$ gave the results similar to those observed with strain N-79.
Table VII. Effect of Initial pH and Addition of $\mathrm{CaCO}_{3}$ on Accumulation of ORGANIC ACIDS

Strain N-79 was cultivated at $30^{\circ} \mathrm{C}$ for 7 days.

\begin{tabular}{|c|c|c|c|c|c|}
\hline $\begin{array}{c}\mathrm{CaCO}_{3} \\
(\%)\end{array}$ & $\begin{array}{l}\text { Initial } \\
\mathrm{pH}\end{array}$ & $\begin{array}{l}\text { Final } \\
\mathrm{pH}\end{array}$ & $\begin{array}{c}\text { Cells } \\
\text { (g/liter) }\end{array}$ & $\begin{array}{r}\alpha \text {-Ketoglu- } \\
\text { taric acid } \\
\text { (mg/liter) }\end{array}$ & $\begin{array}{c}\text { Succinic } \\
\text { acid } \\
\text { (mg/liter) }\end{array}$ \\
\hline & 6.0 & 2.8 & 1.2 & 180 & - \\
\hline & 7.0 & 2.6 & 1.5 & 360 & 100 \\
\hline & 8.0 & 5.0 & 1.6 & - & - \\
\hline 1 & & 5.4 & 1.0 & - & - \\
\hline 3 & & 5.4 & 1.9 & - & - \\
\hline
\end{tabular}

e) pH-controlled culture. The above results suggested that the $\mathrm{pH}$ of culture broth might play an important role in the accumulation of organic acids. For this reason, the $\mathrm{pH}$ controlled culture with strain $\mathrm{N}-79$ was attempted by using the shaking flask method. The organism was inoculated in the medium having the initial $\mathrm{pH}$ of 7.0 and cultivated for a period of 5 days which was enough for abundant growth. The culture flasks were then divided into three groups which were adjusted respectively at three different $\mathrm{pH}$ values of $6.0,5.0$ and 4.0 by adding a solution of $0.1 \mathrm{~N}$ sodium hydroxide once a day. Cultivation was continued for an additional 3 days. The groups of $\mathrm{pH} 6.0$ and 5.0 accumulated no organic acids, whereas the group of $\mathrm{pH} 4.0$ yielded $660 \mathrm{mg} /$ liter of $a$-ketoglutaric acid. Therefore, it is concluded that the accumulation of organic acids by strain $\mathrm{N}-79$ depends greatly on the $\mathrm{pH}$ value in the culture broth and it is necessary that the $\mathrm{pH}$ value be kept at around 4 after the exponential phase of growth.

5. Time course for accumulation of a-ketoglutaric acid and acetone by strain $N-79$

In order to study the time course for the accumulation of $\alpha$-ketoglutaric acid as a major acid by strain $\mathrm{N}-79$, a cultivation experiment was carried out by use of a 10 liter-jar fermentor equipped with a $\mathrm{pH}$ controller. The results are shown in Fig. 3, including the curves of the isopropanol consumption and the acetone formation. The cell growth was accompanied by the drop of $\mathrm{pH}$ value in the broth 


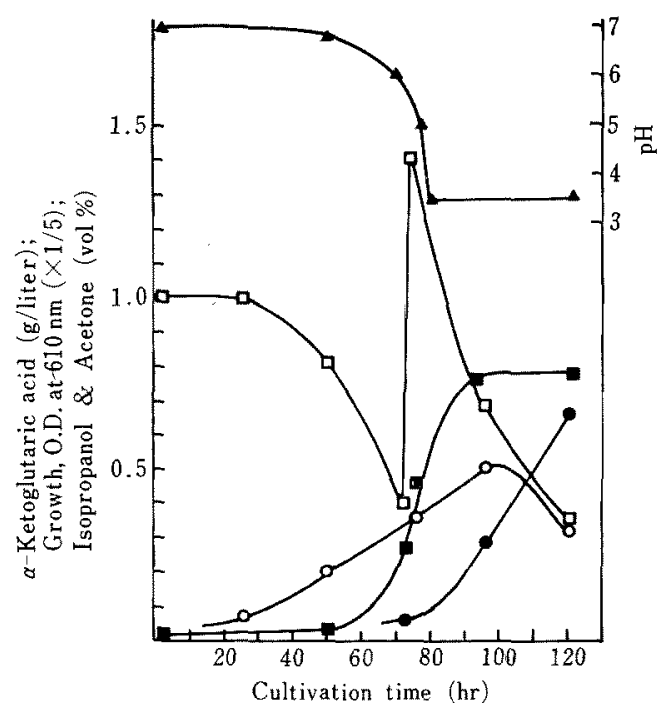

FIG. 3. Time Course of $\alpha$-Ketoglutaric Acid Accumulation from Isopropanol by Strain N-79.

The organism was cultivated in a 10 liter-jar fermentor containing 5 liters of the medium (isopropanol, 1 vol. $\%$ ) at $30^{\circ} \mathrm{C}$. The fermentor was operated at 0.5 liter/ min of air flow and $600 \mathrm{rpm}$ of agitation. At the cultivation time of $72 \mathrm{hr}$, another 1 vol. $\%$ of isopropanol was added to the broth.

- $a$-ketoglutaric acid; $\mathbf{\square}$, growth (O.D); $\square$, isopropanol; $\bigcirc$, acetone; $\wedge, \mathrm{pH}$.

and particularly the rapid drop of $\mathrm{pH}$ was observed in the latter half of the exponential phase. The accumulation of $\alpha$-ketoglutaric acid was initiated in this time of the growth phase, and then the $\mathrm{pH}$ was automatically maintained at 3.5 with the controller. During the period of this controlled culture, the accumulation of $\alpha$-ketoglutaric acid was continued at a rate of about $0.015 \mathrm{~g} / \mathrm{liter} / \mathrm{hr}$. When the $\mathrm{pH}$ value of 3.0 was adopted for use in the controlled culture, the formation of $\alpha$ ketoglutaric acid ceased in a short time and the accumulation of the acid in the broth was restricted at a low level.

Acetone, which is regarded as one of the intermediates in the catabolism of isopropanol, appeared in the broth in the lag phase of growth and was accumulated up to a maximum concentration of $0.5 \%(v / v)$ and then decreased with the progress of the formation of organic acids. o. Formation of $\alpha$-ketoglutaric acid from isopropanol-related compounds by strain $N-$ 79

Isopropanol together with $n$-propanol and acetone has been assumed to be an intermediate in the catabolism of $n$-propane. The resting cell studies of Pabst and Brown ${ }^{6)}$ on a propaneutilizing Mycobaterium have reached the conclusion that isopropanol is catabolized by two separate pathways: one involves the isomerization of isopropanol to $n$-propanol while the other involves a dehydrogenation to acetone. On multiple adaptation experiments with a n-propane-oxidizing Mycobacterium, Klausmeier et $a l^{7}{ }^{\prime \prime}$ postulated the interconversion between isopropanol and $n$-propanol. However, in the incorporation experiments of ${ }^{18} \mathrm{O}$ into $n$-propane-oxidizing Mycobacterium cells, Lukins and Foster ${ }^{8 /}$ have demonstrated that the catabolic pathway of $n$-propanol via isopropanol and acetone is inconceivable. This discrepancy among these studies with respect to the microbial metabolism of isopropanol seems to be ascribable to the operation of different mechanisms in different strains.

Therefore, we were interested to know which type of pathways for the metabolism of isopropanol is operated in strain $\mathrm{N}-79$. The organism was examined for growth on $n$ propane, $n$-propanol, isopropanol and acetone and for the formation of $\alpha$-ketoglutaric acid from these compounds. The data obtained are summarized in Table VIII. The organism

TABlE VIII. Formation OF $\alpha$-Ketoglutaric

ACID FROM ISOPROPANOL-RELATED COMPOUNDS Strain N-79 was cultivated at $30^{\circ} \mathrm{C}$ for 7 days.

\begin{tabular}{lcccc}
\hline $\begin{array}{c}\text { Substrate } \\
(\text { vol. \%) }\end{array}$ & $\begin{array}{c}\text { Final } \\
\mathrm{pH}\end{array}$ & $\begin{array}{c}\text { Cells } \\
\text { (g/liter) }\end{array}$ & $\begin{array}{c}\text { a-Ketoglu- } \\
\text { taric acid } \\
\text { (mg/liter) }\end{array}$ \\
\hline$n$-Propane & $\left.-{ }^{a}\right)$ & 6.8 & \pm & - \\
$n$-Propanol & 2.0 & 4.2 & 1.0 & - \\
Isopropanol & 2.0 & 2.4 & 0.8 & 540 \\
Acetone & 1.5 & 2.6 & 2.0 & 270 \\
\hline
\end{tabular}

a) $n$-Propane was added by replacing $50 \%$ of the air in a closed flask with the gaseous substrate.

was able to grow at the expense of $n$-propanol, isopropanol and acetone, but $n$-propane was 
little or no utilizable carbon source. $\alpha$ Ketoglutaric acid was formed only from isopropanol and acetone but not from $n$ propanol. Acetone was formed, as described above, from isopropanol but not from $n^{-}$ propanol. At any stage of the culture process using isopropanol as the carbon source, $n$ propanol was not detected. From these results, it is concluded that the metabolism of isopropanol by strain $\mathrm{N}-79$ probably proceeds, without the interconversion between isopropanol and n-propanol, exclusively via the acetone pathway.

\section{REFERENCES}

1) H. Ueyama, Y. Yamauchi, N. Tsugi and T. Fukimbara, J. Ferment. Technol., 49, 581 (1971);
J. Ferment. Technol., 50, 223 (1972).

T.Nishimura et al., Japan Kokai, 49-116284(1974);

S. Matsumoto et al., ibid., 49-133582 (1974).

2) Y. Yamauchi et al., ibid., 49-50184 (1974).

3) N. Kurima et al., Japan Patent, 49-34833 (1974).

4) J. Takahashi, Petroleum and Microorganisms (Sekiyu to Biseibutsu), No. 10, 41 (1973).

5) Y. Ishitoya, C. Itoh, N. Osawa, I. Hashimoto and T. Iwanaga, Clin. Chim. Acta, 27, 233 (1970).

6) G. S. Pabst and L. R. Brown, "Development in Industrial Microbiology," Vol.9, ed. by C.J. Corum, American Institute of Biological Sciences, Washington, D. C., 1968, p. 394.

7) R. E. Klausmeier, L. R. Brown, E. N. Benes and R. J. Strawinski, Bacteriol. Proc., 1958, p. 123 ["Advances in Enzymology," Vol. 27, ed. by F. F. Nord, Interscience Publishers, New York, N. Y., 1965, p. 484].

8) H. B. Lukins and J. W. Foster, J. Bacteriol., 85, 1074 (1963). 